\title{
GAMBARAN PENGETAHUAN KELUARGA TENTANG PEMBUANGAN LIMBAH SAMPAH TERHADAP PENCEGAHAN DBD DILINGKUNGAN V KELURAHAN LABUHAN DELI
}

\author{
Sarmaida Siregar ${ }^{1}$, Aureliya Hutagaol ${ }^{2}$, Hamonangan Damanik ${ }^{3}$, Sarida Surya Manurung ${ }^{4}$ \\ ${ }^{1}$ Program Studi D-III Keperawatan, Universitas Imelda Medan \\ ${ }^{2,3,4}$ Program Studi S-1 Keperawatan, Universitas Imelda \\ Email: ${ }^{1}$ sarmaidabahtiar.123@gmail.com, ${ }^{2}$ aureliyanovita@gmail.com, \\ ${ }^{3}$ hamonangandamanik1112@gmail.com, ${ }^{4}$ sarida.manurung1@gmail.com
}

\begin{abstract}
ABSTRAK
Demam Berdarah Dengue (DBD) adalah penyakit menular yang disebabkan oleh virus dengue. Ditularkan oleh nyamuk Aedes aegypti. Ditandai dengan demam mendadak selama dua sampai tujuh hari tanpa penyebab yang jelas, lemas atau lesu, mudah tersinggung, mulas dengan gejala perdarahan yang muncul di kulit berupa bercak berdarah (petechia), ruam (purpura). Tujuan penelitian ini adalah untuk mendeskripsikan pengetahuan keluarga tentang pembuangan limbah sampah terhadap pencegahan DBD di Lingkungan V Kelurahan Medan Marelan. Metode yang digunakan adalah deskriptif yang bertujuan untuk membuat gambaran pengetahuan keluarga tentang pembuangan limbah sampah terhadap pencegahan DBD dengan rancangan cross sectional. Pada penelitian ini mengunakan kuesioner dalam pengumpulan data. Populasi dalam penelitian seluruh keluarga yang tinggal di Lingkungan V Kelurahan Medan Marelan dan salah satu anggota keluarganya pernah menderita penyakit DBD. Jumlah populasi adalah sebanyak 37 orang dan sampel yang diambil dengan tehnik total sampling yaitu 37 orang. Identifikasi pengetahuan Keluarga tentang pembungan limbah sampah terhadap pencegahan DBD menggunakan instrumen dalam bentuk kuisioner tertutup. Berdasarkan hasil penelitian mayoritas pengetahuan keluarga cukup sebanyak 18 responden (48\%) dan minoritas baik sebanyak 9 responden (24\%), Untuk itu masih sangat penting penyuluhan pada keluarga tentang pembungan limbah sampah terhadap pencegahan DBD di Lingkungan V Kelurahan Medan Marelan agar tercapai kategori pengetahuan keluarga baik.
\end{abstract}

Kata Kunci: Pengetahuan, Keluarga, Limbah, Sampah, DBD.

\section{ABSTRACT}

Dengue Hemorrhagic Fever (DHF) is an infectious disease caused by the Dengue virus and transmitted by the Aedes aegypti mosquito which is characterized by a sudden fever of two to seven days without apparent cause, weakness or lethargy, anxiety, heartburn, accompanied by signs bleeding in the skin in the form of bleeding spots (petechia), rashes (purpura). The purpose of this is to describe family knowledge about waste disposal against DHF prevention in the V Environment in Medan Marelan Kelurahan. The method used in this study is descriptive which aims to make a description of the family's knowledge about waste disposal against DHF prevention with a cross sectional design. In this study using a questionnaire in data collection. The population in the study was all families living in the Medan $V$ neighborhood, Medan Marelan and one of his family members had suffered from dengue disease. The total population is 37 people and the sample taken with a total sampling technique is 37 people. Identification of family knowledge about waste disposal of dengue prevention using instruments in the form of a closed questionnaire. Based on the results of the study, the majority of family knowledge is sufficient as many as 18 respondents (48\%) and a good minority of 9 respondents (24\%) nice family.

Keywords: Knowledge, Family, Waste, Waste, DHF.

\section{PENDAHULUAN}

Penyakit Demam Berdarah Dengue (DBD) merupakan penyakit menular yang disebabkan oleh virus dengue. Ditularkan oleh nyamuk Aedes aegypti. Ditandai dengan demam mendadak selama dua sampai tujuh hari tanpa sebab yang jelas, lemas atau lesu, mudah tersinggung, Mulas, disertai dengan tanda perdarahan, muncul pada kulit berupa bercak perdarahan (petechia), ruam (purpura). Kadang mimisan, disentri, muntah darah, penurunan kesadaran, dan kecenderungan menyebabkan sengatan listrik 
(sengatan listrik) dan kematian (Mubin, 2009).

Penyakit Demam Berdarah Dengue (DBD) merupakan penyakit yang ditemukan di sebagian besar daerah tropis dan subtropis, terutama Asia Tenggara, Amerika Tengah, Amerika dan Karibia. Host alami DBD adalah manusia, dan patogennya adalah virus Dengue dari family Flaviviridae. Flavivirus genus mencakup empat serotipe yaitu Den-1, Den-2, Den-3 dan Den-4 yang ditularkan ke manusia melalui gigitan nyamuk yang terinfeksi, terutama Aedes aegypti dan Aedes aegypti.Albinisme. Masa inkubasi (masa inkubasi internal) virus dengue dalam tubuh manusia adalah antara 3 hingga 14 hari sebelum timbulnya gejala. Gejala klinis ratarata muncul pada hari keempat hingga ketujuh, sedangkan masa inkubasi eksternal (pada nyamuk) berlangsung sekitar 8 sampai 10 hari (Candra, 2010).

Demam berdarah adalah penyakit arbovirus paling umum dan utama, dengan 5 miliar hingga 100 juta kasus dilaporkan setiap tahun, dengan sekitar 500.000 kasus parah dan 20.000 kasus fatal. Data dari Organisasi Kesehatan Dunia (WHO) menunjukkan bahwa meskipun hampir 40\% penduduk dunia tinggal di daerah endemik DBD, meskipun terdapat banyak sumber daya untuk pemantauan dan pengendalian demam berdarah, beberapa negara telah berhasil mengendalikan demam berdarah (Resende et al., 2013).

$$
\text { Menurut data World Health }
$$

Organization (WHO, 2014) demam berdarah dengue pertama kali dilaporkan di Asia Tenggara (Filipina) pada tahun 1954, kemudian menyebar ke berbagai negara. Sebelum tahun 1970 hanya ada 9 negara yang terjangkit DBD, namun sekarang DBD mewabah di lebih dari 100 negara, antara lain Afrika, Amerika, Mediterania Timur, Asia Tenggara dan Pasifik Barat yang merupakan negara dengan kejadian DBD tertinggi. Jumlah kasus di Amerika Serikat, Asia Tenggara dan kawasan Pasifik Barat melebihi 1,2 juta pada 2008 dan 2,3 juta pada 2010.

Pada 2013, Amerika Serikat melaporkan 2,35 juta kasus, di mana 37.687 di antaranya adalah demam berdarah parah. Menurut laporan Organisasi Kesehatan Dunia (WHO), kasus demam berdarah global berkembang dari 980 kasus di hampir 100 negara pada tahun 1954-1959 menjadi 1.016.612 kasus di hampir 60 negara pada tahun 2000-2009 (WHO, 2014).

Demam berdarah dengue (DBD) masih menjadi salah satu masalah kesehatan masyarakat terpenting di Indonesia, seiring dengan meningkatmya mobilitas dan kepadatan penduduk, jumlah penderita dan luas daerah penyebarannya semakin bertambah di Indonesia, demam berdarah pertama kali di temukan di Kota Surabaya pada tahun 1968 dimana sebanyak 58 orang terinfeksi dan 24 orang di nyatakan meninggal dunia, dengan Angka Kematian (AK) mencapai $41 \%$ sejak saat itu penyakit ini menyebar luas ke seluruh Idonesia. (Kemenkes RI, 2011).

DBD merupakan salah satu penyakit menular yang sering menyebabkan kejadian Luar Biasa (KLB) di Indonesia, DKI Jakarta merupakan salah satu tempat wabah penyakit yang sering terjadi, merupakan ibu kota negara Indonesia dengan jumlah penduduk yang besar. Masalah ini sangat mendukung Jakarta menjadi daerah edemik DBD. Dimana penduduk yang banyak, lingkungan yang padat dan arus urbanisasi yang tinggi menjadikan Jakarta kota memiliki pernasalah lingkungan (Kemenkes RI, 2011).

Sulitnya menurunkan insiden DBD di Jakarta merupakan tantangan sendiri bagi DKI Jakarta. Hal ini perlu di kaji lebih lebih jauh mengingat sudah adanya program kader Jumantik. Menjadi tanda tanya besar sesungguhnya bagaimana praktik pencegahan DBD yang berjalan di wilayah DKI Jakarta, terutama di Jakarta Timur. Perlu dikaji lebih lanjut praktik pencegahan apa sajakah yang dilakukan oleh masyarakat setempat. Upaya penanggulangan virus dengue melalui kampanye PSN membutuhkan ketekunan, semangat dan partisipasi masyarakat, oleh karena itu diperlukan penelitian untuk menguraikan perilaku sehat terkait praktik pencegahan DBD di daerah dengan DBD tinggi. (Kementerian Kesehatan Provinsi RI, 2011)

Pada tahun 2012 terdapat 4367 kasus DBD di Provinsi Sumatera Utara, dengan IR (angka kejadian) 33 per 100.000 penduduk; pada tahun 2013 terdapat 4.732 kasus DBD di Provinsi Sumatera Utara, IR As berikut: ada 35,5 kasus per 100.000 orang, jumlah kasus meningkat menjadi 7.140 pada tahun 2014, dan IR 51,9 per 100.000 orang. Kolera telah menyebar luas di Sumatera Utara 
dengan morbiditas dan mortalitas yang relatif tinggi. Menurut KLB, Sumatera Utara dapat dibedakan menjadi daerah endemis DBD, DBD sporadis dan daerah berpotensi atau daerah bebas DBD. Upaya-upaya pencegahan kejadian luar biasa (KLB) sudah seharusnya dilakukan secara komprensif. Baik pada tingkat kelompok maupun pada tingkat individu, salah satunya pada tingkat kelompok dengan merubah perilaku masyarakat.

Perilaku masyarakat dalam menjaga kebersihan lingkungan sekitar rumah menjadi salah satu faktor terkait penyakit DBD. Penelitian yang dilakukan oleh (Mahardika, 2009) menunjukkan bahwa masih banyak penderita DBD yang membuang sampahnya. Kebiasaan membuang sampah di sini terkait erat dengan keberadaan nyamuk Ae.aegypti berfungsi sebagai pembawa infeksi dengue. Ini karena Ae.aegypti bisa berkembang biak di tempat sampah. $4 \mathrm{Hal}$ ini terkait erat dengan cara masyarakat menangani sampah. Penelitian yang dilakukan oleh (Endang Puji Restuti, 2016) di Jawa Barat menunjukkan bahwa sebagian besar masyarakat masih menggunakan metode pembakaran untuk membuang sampah, dan nyamuk dapat berkembang biak disini. Trias ilmu epidemiologi menjelaskan hubungan antara tiga faktor utama yang berperan dalam terjadinya penyakit dan gangguan kesehatan, yaitu inang (inang), patogen (faktor penyebab), dan lingkungan (environment): masyarakat memelihara lingkungan sekitarnya. Kebersihan rumah merupakan salah satu faktor yang berhubungan dengan demam berdarah. Penelitian yang dilakukan oleh (Mahardika, 2009) menunjukkan bahwa masih banyak penderita DBD yang membuang sampah. Kebiasaan membuang sampah di sini terkait erat dengan keberadaan nyamuk Ae.aegypti berfungsi sebagai pembawa infeksi dengue. Ini karena Ae.aegypti bisa berkembang biak di tempat sampah. Hal ini terkait erat dengan cara masyarakat menangani sampah.

Dari Survey awal yang penulis terhadap beberapa keluarga lakukan di Kelurahan Labuhan Deli Lingkungan V Kecamatan Medan Marelan, masih banyak keluarga yang belum mengetahui tentang pembuangan limbah sampah. Dalam konteks diatas, penulis tertarik untuk melakukan penelitian dengan judul tersebut "Gambaran
Pengetahuan Keluarga tentang Pembuangan Limbah Sampah terhadap Pencegahan DBD di Lingkungan $\mathrm{V}$ Kelurahan Medan Marelan".

\section{METODE}

Jenis penelitian ini bersifat deskripsi yaitu untuk mengetahui gambaran pengetahuan keluarga tentang pembuangan limbah sampah terhadap pencegahan DBD di Lingkungan V Desa Labuhan Deli Kecamatan Medan Marelan dengan menggunakan pendekatan cross sectional yaitu penelitian sectional silang yang diukur dan dikumpulkan secara simultan atau secara bersamaan dan data yang dikumpulkan pada waktu tertentu untuk menggambarkan keadaan waktu itu, dimana bertujuan untuk menetapkan pertanyaan, mengidentifikasi setiap variabel, objek, pengukuran dan analisis penelitian (Setiadi, 2009).

Waktu dalam penelitan ini dilakukan bulan Maret - Mei tahun 2019. Penelitian di lakukan di Lingkungan V Desa Labuhan Deli Kecamatan Medan Marelan. Adapun yang menjadi populasi pada penelitian ini adalah seluruh keluarga yang salah satu anggota keluarganya pernah menderita penyakit DBD di Lingkungan V Desa Labuhan Deli Kecamatan Medan Marelan berjumlah dan berjumlah 37 kepala keluarga. Teknik pengambilan sampel pada penelitian ini adalah Probability Sampling yaitu memberi kesempatan kepada semua populasi untuk menjadi sampel dengan menggunakan Total Sampling dimana seluruh populasi dijadikan sampel penelitian (Setiadi, 2009).

Sampel adalah bagian dari keseluruhan objek yang di teliti dan dianggap menjadi seluruh atau sebagian pupulasi. Sampel dalam penelitian ini berjumlah 37 kepala keluarga. Sebelum proses pengumpulan data dilakukan, tahap awal dari proses ini adalah melakukan persiapan untuk melancarkan pelaksanaan penelitian dengan cara melakukan pendekatan pada responden guna menjelaskan makna dan tujuan penelitian. Peneliti wajib menjelaskan kepada responden bahwa penelitian tidak berdampak negatif kepada fisik, mental dan kerahasiaan responden sangat terjaga.

Data yang digunakan dalam penelitian adalah sebagai berikut: 
1. Data Primer

Data primer yaitu, data yang didapat dari responden dan dikumpulkan secara khusus untuk menjawab pertanyaan penelitian ini, meliputi:

a. Data tentang identitas klien meliputi inisial nama, umur, pekerjaan, pendidikan, jenis kelamin dikumpulkan dengan kuesioner.

b. Data penyuluhan kesehatan dikumpulkan dengan kuesioner.

c. Data upaya pencegahan dikumpulkan dengan kuesioner.

2. Data Sekunder

Data sekunder merupakan data yang mendukung penelitian data sekunder dapat diperoleh dari berbagai sumber, diantaranya yaitu instansi terkait dengan penelitian, buku-buku, dan artikel.

3. Data Tersier

Yaitu data yang didapat dari hasil penelitian atau jurnal terdahulu.

Variabel adalah sesuatu yang digunakan sebagai ciri, ciri atau ukuran kepemilikan atau perolehan, atau unit penelitian dari suatu konsep makna, seperti usia, jenis kelamin, tingkat pendidikan, status perkawinan, pekerjaan, pengetahuan, pendapatan, penyakit dll (Notoatmodjo, 2012). Variabel dan penelitian adalah pengetahuan keluarga. Definisi operasional adalah semua variabel dan istilah yang akan digunakan secara operasional, sehingga pada akhirnya memudahkan pembaca dalam menjelaskan penelitian

Pengetahuan keluarga adalah segala sesuatu yang diketahui keluarga tentang pembuangan limbah sampah terhadap pencegahan DBD di Lingkungan V Desa Labuhan Deli Kecamatan Medan Marelan. Teknik pengukuran yang dilakukan peneliti dengan kuesioner tertutup kepada responden sebanyak 24 pertanyaan untuk variabel pengetahuan diformulasikan variabel respon interval menggunakan rumus Sturges untuk menentukan standar respon responden:

$I=\frac{\mathrm{R}}{\mathrm{K}}=\frac{\text { Nilai Tertinggi }- \text { Nilai Terendah }}{\text { Kelas }}$

\section{Keterangan :}

$\mathrm{I}=$ Interval kelas

$\mathrm{R}=\mathrm{Jarak}$ kelas (Skor Maksimal-Skor

Minimal)

K=Jumlah (Kategori) (Sudjana, 2009).
Sedangkan untuk mengetahui presentase jawaban responden dengan kriteria responden, menggunakan rumus:

$$
\mathrm{P}=\frac{\mathrm{F}}{\mathrm{N}} \times 100 \%
$$

\section{Keterangan :}

$\mathrm{P}=$ persentase

$\mathrm{F}=$ Jawaban yang benar

N= Jumlah Pertanyaan (Setiadi, 2007)

Pada variabel pengetahuan dengan menggunakan skala Guttman apabila jika jawaban penjawab salah, itu 0, dan jika jawaban penjawab benar, itu adalah 1 sehingga kriteria jawaban responden dapat disimpulkan melalui nilai dan presentase jawaban sebagai berikut:

$\mathrm{I}=\frac{\mathrm{R}}{\mathrm{K}}=\frac{\text { Nilai Tertinggi }- \text { Nilai Terendah }}{\text { Kelas }}$

$\mathrm{I}=\frac{24-0}{3}=8$

Keterangan:

I = Interval

$\mathrm{K}=$ Jumlah (kategori)

Range $=$ Skor maksimal - skor minimal

Sedangkan untuk mengetahui presentase jawaban sesuai dengan kriteria responden memakai rumus Determinan oleh (Setiadi, 2009), yaitu:

$\mathrm{P}=\frac{\mathrm{F}}{\mathrm{N}} \times 100 \%$

Keterangan :

$\mathrm{P}=$ perensentase

$\mathrm{F}=$ jumlah jawaban yang benar

$\mathrm{N}=$ jumlah soal

Tabel 1. Interval Jawaban Kategori Pengetahuan

\begin{tabular}{cccc}
\hline No & $\begin{array}{c}\text { Kategori } \\
\text { Pengetahuan }\end{array}$ & $\begin{array}{c}\text { Skor } \\
\text { Jawaban }\end{array}$ & $\mathbf{( \% )}$ \\
\hline 1 & Baik & $17-24$ & $71-100$ \\
\hline 2 & Cukup & $9-16$ & $37-66$ \\
\hline 3 & Buruk & $0-8$ & $0-33$ \\
\hline
\end{tabular}

Ada beberapa kegiatan yang dilakukan oleh peneliti dalam pengolahan data/analisis data, dibagi menjadi beberapa tahap yaitu:

1. Editing (memeriksa)

Digunakan untuk memeriksa daftar pertanyaan yang diajukan oleh pengumpul data. Periksa daftar pertanyaan lengkap berdasarkan kelengkapan jawaban, keterbacaan tulisan dan relevansi jawaban. 
2. Coding (memberi tanda/kode)

Mengkategorikan jawaban responden. Biasanya klasifikasi dilakukan dengan memberikan simbol / kode berupa angka pada setiap jawaban. Sorting adalah mengurutkan dengan memilih atau mengelompokkan data sesuai dengan jenis yang diinginkan.

3. Sorting (sortir)

Merupakan dengan memilih atau mengelompokkan data sesuai dengan jenis yang diinginkan.

4. Entry Data (memasukkan data)

Jawaban untuk kode kategori yang diberikan dimasukkan ke dalam formulir. Penginputan data dapat dilakukan secara manual atau diolah dengan komputer.

5. Cleaning

Adalah tahap memastikan bahwa seluruh data yang telah dimasukkan kedalam pengolahan data selesai dengan sebenarnya (Setiadi, 2007).

\section{HASIL DAN PEMBAHASAN}

\subsection{Hasil}

Setelah dilakukan penelitian terhadap 37 responden dengan judul Gambaran Pengetahuan Keluarga Tentang Pembuangan Limbah Sampah Terhadap Pencegahan DBD di lingkungan V Desa Labuhan Deli Kecamatan Medan Marelan kemudian hasilnya ditampilkan pada tabel distribusi dibawah ini:

\section{Data Umum}

Tabel 2. Distribusi Karakteristik Responden

\begin{tabular}{cccc}
\multicolumn{4}{c}{ Berdasarkan Umur } \\
\hline No & Umur (tahun) & (f) & $\mathbf{( \% )}$ \\
\hline 1 & $30-34$ & 16 & $43 \%$ \\
\hline 2 & $35-39$ & 1 & $57 \%$ \\
\hline & Total & $\mathbf{3 7}$ & $\mathbf{1 0 0}$
\end{tabular}

Dari tabel diatas dijelaskan bahwa dari 37 responden mayoritas responden berumur 35-39 sebanyak 21 responden (57\%) dan minoritas berumur 30-34 sebanyak 16 responden $(43 \%)$.

Tabel 3. Distribusi Karakteristik Responden Berdasarkan Pendidikan

\begin{tabular}{cccc}
\hline No & Pendidikan & $(\mathbf{F})$ & $\mathbf{( \% )}$ \\
\hline 1 & SD & 5 & 14 \\
\hline 2 & SMP & 10 & 27 \\
\hline 3 & SMA & 20 & 54 \\
\hline 4 & D III/S I & 2 & 5 \\
\hline & Total & $\mathbf{3 7}$ & $\mathbf{1 0 0}$ \\
\hline
\end{tabular}

Dari tabel diatas dapat dijelaskan bahwa dari 37 responden mayoritas berpendidikan SMA sebanyak 20 responden (54\%), pendidikan SMP sebanyak 10 responden (27\%) pendidikan SD sebanyak 5 (13\%) dan minoritas berpendidikan D III/S I sebanyak 2 responden $(5 \%)$.

Tabel 4. Distribusi Karakteristik Responden Berdasarkan Pekerjaan

\begin{tabular}{clcc}
\hline No & Pekerjaan & (F) & $\mathbf{( \% )}$ \\
\hline 1 & IRT & 12 & 32 \\
\hline 2 & Wiraswasta & 8 & 21 \\
\hline 3 & Karyawan Swasta & 7 & 10 \\
\hline 4 & Buruh Harian Lepas & 10 & 27 \\
\hline & Total & $\mathbf{3 7}$ & $\mathbf{1 0 0}$ \\
\hline
\end{tabular}

Dari tabel diatas dapat dijelaskan bahwa dari 37 responden mayoritas responden bekerja sebagai IRT sebanyak 12 responden $(32 \%)$, pekerjaan buruh harian lepas sebanyak 10 responden (27\%) pekerjaan wiraswasta sebanyak 8 responden $(21 \%)$ dan minoritas pekerjaan karyawan swasta sebanyak 7 responden (10\%).

Tabel 5. Distribusi Karakteristik Responden Berdasarkan Sumber Informasi

\begin{tabular}{cccc}
\hline No & Sumber Informasi & (F) & $\mathbf{( \% )}$ \\
\hline 1 & Media Cetak & 7 & 18 \\
\hline 2 & Media Elektronik & 5 & 13 \\
\hline 3 & Tenaga Kesehatan & 15 & 41 \\
\hline 4 & Keluarga & 10 & 27 \\
\hline & Total & $\mathbf{3 7}$ & $\mathbf{1 0 0}$ \\
\hline
\end{tabular}

Dari tabel diatas dapat dijelaskan bahwa dari 37 responden mayoritas mendapat informasi dari media cetak sebanyak 7 (18\%) media Elektronik 5 (13\%) Tenaga Kesehatan $15(41 \%)$ Keluarga $10(27 \%)$.

\section{Data Khusus}

Tabel 6. Distribusi Karakteristik Responden Berdasarkan Pengetahuan

\begin{tabular}{cccc}
\hline No & Pengetahuan & $(\mathbf{F})$ & $\mathbf{( \% )}$ \\
\hline 1 & Baik & 9 & 24 \\
\hline 2 & Cukup & 18 & 49 \\
\hline 3 & Buruk & 10 & 27 \\
\hline & Jumlah & $\mathbf{3 7}$ & $\mathbf{1 0 0}$ \\
\hline
\end{tabular}

Dari tabel diatas dapat dijelaskan bahwa 37 pengetahuan responden mayoritas cukup sebanyak 18 responden (49\%), yang memiliki pengetahuan buruk sebanyak 10 responden (27\%), dan minoritas responden berpengetahuan baik sebanyak 9 responden $(24 \%)$. 


\subsection{Pembahasan}

Berdasarkan

data responden

"Pengetahuan Keluarga Tentang Pembuangan Limbah Sampah Terhadap Pencegahan DBD di lingkungan V Desa Labuhan Deli Kecamatan Medan Marelan", menunjukkan bahwa dari 37 orang yang menjadi responden mayoritas memiliki pengetahuan cukup sebanyak 18 responden (49\%), dan minoritas pengetahuan baik sebanyak 9 responden (24\%). Hasil penelitian ini sesuai dengan pendapat (Notoatmodjo, 2009), semakin tua usia seseorang maka semakin berkembang pemahaman dan cara berpikirnya, sehingga ilmu yang diperoleh semakin baik.

Semakin tinggi tingkat pendidikan seseorang maka semakin mudah orang tersebut memperoleh informasi kesehatan dan menginformasi kesehatan yang diperolehnya. Dimana mayoritas berpendidikan SMA sebanyak sebanyak 20 responden (54\%), dan minoritas pendidikan DIII/S1 sebanyak 2 responden (5\%), sedangkan sumber informasi mayoritas dari tenaga kesehatan 15 orang (41\%), dari tenaga kesehatan sebanyak 10 responden (27\%), dari teman/lingkungan sebanyak 6 responden $(16 \%)$ dan minoritas dari media elektronik sebanyak 5 orang $(13 \%)$.

\section{KESIMPULAN}

Berdasarkan analisa data dalam penelitian yang telah dilakukan maka dapat disimpulkan sebagai berikut:

1. Gambaran Pengetahuan Keluarga Tentang Pembuangan Limbah Sampah Terhadap Pencegahan DBD Di Lingkungan V Desa Labuhan Deli Kecamatan Medan Marelan. Hasil penelitian ini di pengaruhi oleh usia (mayoritas responden 30-34 tahun) dan pendidikan (mayoritas responden lulusan SMA) yang mempengaruhi pengetahuan, semakin tua usia seseorang maka semakin berkembang pemahaman dan cara berpikirnya, sehingga ilmu yang diperoleh semakin baik. Semakin tinggi tingkat pendidikan seseorang makan semakin mudah orang tersebut memperoleh informasi dan informasi kesehatan yang diperolehnya.

2. Gambaran Pengetahuan Keluarga Tentang Pembuangan Limbah Sampah Terhadap Pencegahan DBD Di Lingkungan V Desa Labuhan Deli Kecamatan Medan Marelan, mayoritas dengan kategori Pengetahuan
Cukup, dimana hasil penelitian antara pengetahuan dan sikap sama dengan kategori mayoritas cukup. Hasil penelitian ini selain usia dan pendidikan, bahwa dalam hal ini pengetahuan sangat diperlukan atau dibutuhkan dalam menentukan sikap yang terlihat dalam perilaku seseorang. Dalam hal ini pengetahuan sangat diperlukan atau dibutuhkan dalam menentukan sikap yang terlihat dalam perilaku seseorang dan juga dipengaruhi pekerjaan ibu yang mayoritas ibu rumah tangga yang kesehariannya menghabiskan waktu dirumah.

\section{REFERENCES}

Azwar. (2019). Prinsip-prinsip Kesehatan. Jakarta: Binarupa Aksara Cipta.

Antholeo. (2010). Faktor-faktor yang Berhubungan Dengan Kejadian Tuberculosis.

Diakses pada tanggal 13 Juli 2013. http:/ antholeo.wordpress.com/2010/07/08fakt or-faktor-yang-berhubungan-dengankejadian-Tuberculosis.

Asrori. (2009). Gambaran Pengetahuan. Diakses pada tanggal 11 Juli 2013. http://Asrori.blogspot.com/2009/09/Gam baran-Pengetahuan.html.

Decha. (2013) Faktor Penyebab dan Pencegah Dermatitis. Diakses pada tanggal 3 Juli 2013. http://health.lintas.me/article/health.kom pas.com/ilmu-penyakit-dermatitis

Hetharia, R. (2009) Asuhan Keperawatan Gangguan Pernafasan. Jakarta: Trans Info Media.

Herlisa, P. (2008). Cara mencegah Penyakit Tuberculosis. Diakses pada tanggal 3 Juli 2013. http:/www.semarang-eyecenter.com/v1.1/index.php?option=com _content\&view=article\&id.

Intan, S. (2013). Penyakit Tuberculosis. Diakses pada tanggal 4 Juli 2013. Juli 2013. http:/www.read.sariintan/0641 5832.2013.tanda-gejala-Tuberculosis.

Irwan. (2011). Tuberculosis dan Alergi. Diakses pada tanggal 3 Juli 2013. Irwan.blogspot.com/2011/10/penyakittuberculosis-dan-alergi.

Lestari. (2011). Penyakit Tuberculosis. Diakses pada tanggal 11 Juli 2013. http:/www.blogdokter.net.penyakittuberculosis-penyakit-pernafasan. 
Maharani (2009). Asuhan Keperawatan Gangguan Sistem Pernafasan. Diakses pada tanggal 11 Juli 2013 http:/www.blogspot.com/2011/02/04/pe nyakit-tuberculosis-penyakit-pernafasan.

Maya. (2013). Senandung Doa Ibu. Jakarta: Hikmah Suwada.

Muttaqin, E. (2011). Asuhan Keperawatan Gangguan Sistem Pernafasan. Jakarta: Salemba Medika.

Notoatmodjo. (2007). Kesehatan Masyarakat Ilmu Dan Seni. Jakarta: Rineka Cipta.

Notoatmodjo. (2007). Pendidikan Kesehatan dan Ilmu Perilaku. Jakarta: Rineka Cipta.

Pamela, R. (2011). Pengobatan Penyakit Tuberculosis. Diakses pada tanggal 11
Juli

2013.

http:/www.blogdokter.net/2011/02/04/ek sim-tuberculosis-penyakit-paru.

Posted. (2009). Keluarga dan Pasien. Diakses pada tanggal 10 Juli 2013 http:www.health.kompas.com/posted/20 09.

Setiadi. (2007). Konsep dan Penulisan Riset Keperawatan. Edisi I. Yogyakarta: Graha Ilmu.

Zakiuddin, M. (20013) Tuberculosis Atopik Pada Pasien. Diakses pada Tanggal 2 Juli

http:/www.health.kompas.com/read/201 3/tuberculosis-atopik-pada-pasien.

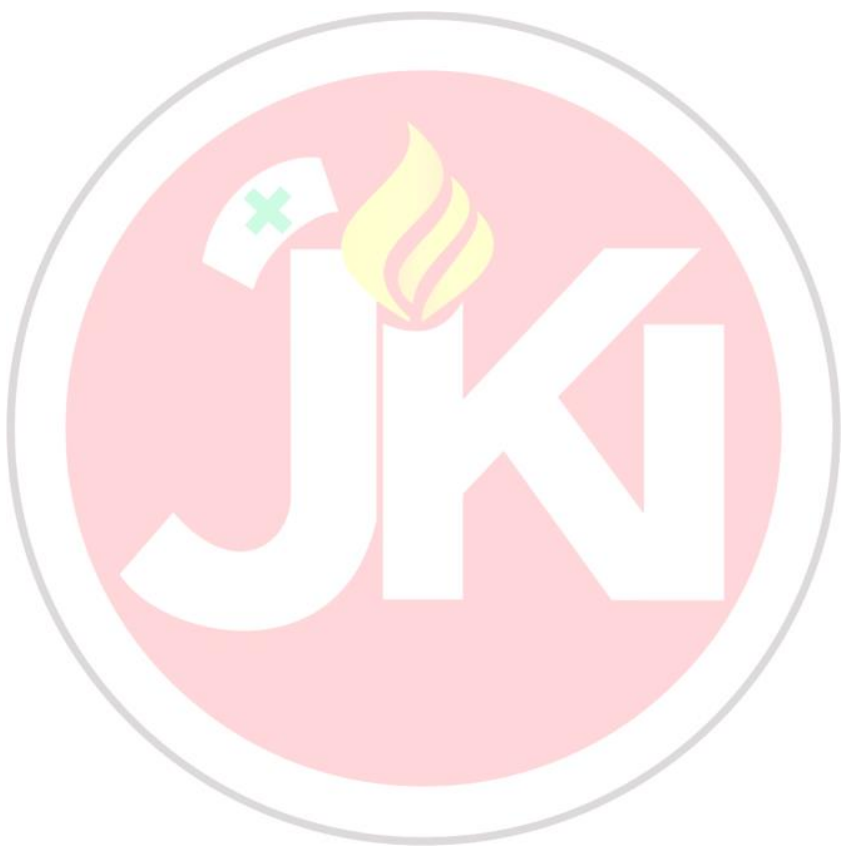

